Chinese cross-border mergers and acquisitions in the developing world: Is Africa unique?

Saileshsingh Gunessee and Shuang Hu

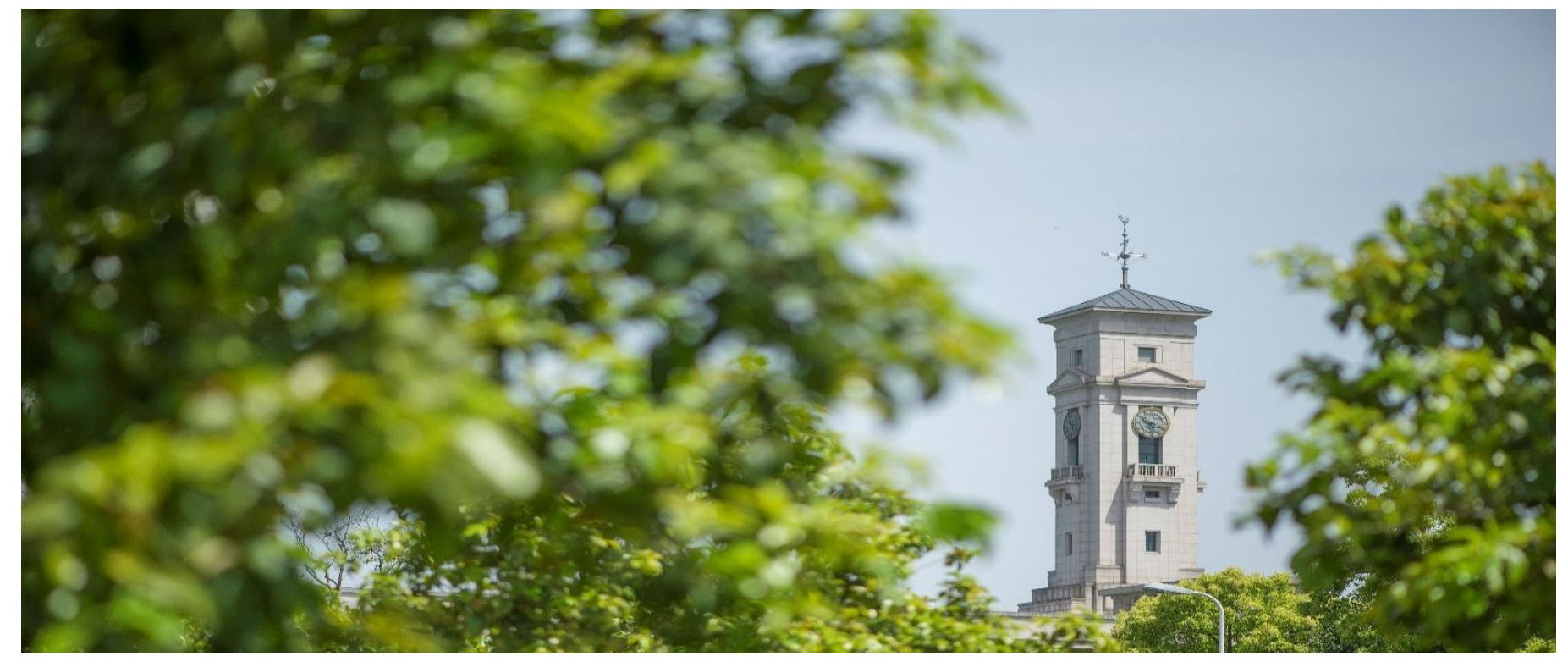


University of Nottingham Ningbo China, 199 Taikang East Road, Ningbo, 315100, Zhejiang, China.

First published 2020

This work is made available under the terms of the Creative Commons Attribution 4.0 International License:

http://creativecommons.org/licenses/by/4.0

The work is licenced to the University of Nottingham Ningbo China under the Global University Publication Licence:

https://www.nottingham.edu.cn/en/library/documents/researchsupport/global-university-publications-licence-2.0.pdf 


\title{
Chinese Cross-Border Mergers \& Acquisitions in the Developing World: Is Africa Unique?
}

\author{
Saileshsingh Gunessee ${ }^{* * *}$ \\ Nottingham University Business School China, University of Nottingham Ningbo China, \\ 199 Taikang East Road, Ningbo 315100, China. \\ Email: saileshsingh.gunessee@ nottingham.edu.cn \\ Phone: +86(0) $57488180000-8231$
}

Shuang $\mathrm{Hu}$

International Doctoral Innovation Centre, School of Economics, University of Nottingham Ningbo China,

199 Taikang East Road, Ningbo 315100, China.

Email: shuang.hu@ nottingham.edu.cn

Phone: + 86(0) 15726810855

$* * *$ Corresponding author 


\section{Executive summary:}

China has emerged as an important partner for Africa. Not surprisingly, Chinese business and investment relations with Africa have been growing. This paper contends that Africa offers a different proposition to Chinese business interests in non-African developing economies. In this optic, it takes a "comparative" institution-based view treating factors that determine Chinese multinationals' cross-border merger and acquisition (CBMA) decisions as comparatively different for Africa to the rest of the developing world. From a panel data estimation of the number of Chinese cross-border mergers \& acquisitions (CBMAs) from 2007 to 2016, we find of market size, natural resources, strategic assets, labor productivity and institutional governance, only natural resources and market size have a distinctive effect, with Chinese investors being more attracted to African natural resources than the African market. The drive for natural resources provides impetus for Chinese MNEs to choose CBMAs over greenfield investment, and through majority ownership to exercise control. Our inference is that Africa is 'significantly' different from other developing regions, in terms of CBMAs, as Chinese multinationals have a strong motive to control access to natural resources.

Keywords: Chinese Multinationals, Acquisitions, Institutions, Africa, Natural Resources.

\section{Introduction}

China-Africa economic engagement has been rising in recent times. For example, China has become Africa's largest trading partner replacing the US. Similarly, Chinese FDI in Africa has witnessed a substantial increase, for instance, in 2003, Chinese FDI to Africa was about 0.49 billion US dollars, while the comparative number in 2018 was 46.1 billion (UNCTAD, 2019). Not surprisingly, the studies of Chinese FDI in Africa has garnered some interest (Biggeri and Sanfilippo, 2009, Kolstad and Wiig, 2011, Cheung et al., 2012, Chen et al., 2016, Mourao, 2018). However, a lesser known phenomenon is Chinese CBMAs in Africa. Though this type of investment or establishment mode is still a nascent part of growing Chinese CBMA in the world (relative to greenfield investment), it begs the question of how different Chinese CBMAs in African economies are to other developing countries.

Our contribution is at the intersection of two streams of the literature: Chinese CBMAs and CBMAs in Africa - with emphasis on providing a comparative perspective between Africa and other developing regions. While there have been studies of CBMAs in the African context (e.g. 
Oguji and Owusu, 2015; Degbey and Ellis, 2017), they mainly focus on CBMAs undertaken by developed economies' firms but do not explore the subject of a developing economy, such as China, as the source of investment. In addition, African economies as an investment target market are different from other developing nations. To bridge the gap, we use a 'comparative institution-based' view to develop a theoretical framework of Chinese CBMAs in the non-African developing world and how they contrast with those in Africa. The antecedents of Chinese CBMA decisions are expounded in this context. We examine how market-seeking, resource-seeking, strategic assetsseeking, and efficiency-seeking locational motives impinge on Chinese multinationals' takeover and location decisions through this comparative institutional lens.

This paper is motivated by two other questions. One is the difference between CBMA and greenfield investment. Motivations for CBMA can be quite distinct to that of greenfield investment and in fact, the so-called 'strategic assets seeking motive' is often primarily seen as an acquisition motive (Dunning and Lundan, 2008). The next question is ownership strategy (voice and control) acquisition with an ownership strategy that allows voice and control, and that allows for voice only. A higher degree of managerial control granted by ownership stakes in target firms can be crucial for securing the control of acquired resources (Chari and Chang, 2009).

The main contributions of this study are twofold. Firstly, it offers answers to the question of what shapes Chinese acquisitions, including both their entry strategies and ownership strategies in developing economies. Moreover, it deepens our understanding of whether Chinese investors treat Africa differently. There are broad implications to our answers. It has been argued that Chinese investment in Africa is incentivized by the pull of natural resources and that this occurs irrespective of the weak institutional setting of the continent, albeit with some challenges to this notion from some quarters (see Brautigam, 2009; Chen et al., 2018). Our study can shed light on this debate.

This paper is organized as follows; Section 2 provides a brief theoretical background of CBMAs with special reference to China and sets up our hypotheses. We discuss the data and research methodology in Section 3. The results are highlighted in Section 4, followed by a concluding section.

\section{Theoretical background and hypotheses development}

\subsection{Comparative institution-based view}


Institutional theory suggests that business strategy and performance are affected by institutions, which are defined as cultural-cognitive, normative and regulative structures and activities (Scott, 2013). Both formal rules and informal constraints of a particular institutional framework set up the rules that organizations, in conducting value-added activities, must follow (Scott, 2013; Dunning and Lundan, 2008). Institutional reconfiguration and upgrading deeply influence firms' learning and resource allocative goals. For instance, an appropriate legal system structure, well-designed financial institutions and a well-protected intellectual property rights system are believed to facilitate the value-adding activities and economic growth of businesses (North, 2005). As such, determinants of MNE's strategic choices extend beyond economic optimization and strategic justification to forces shaped by political, legal and social rules, and by the broader political context surrounding the decision to internationalize (Oliver, 1997; Peng et al., 2008).

However, evidence shows that institutional development is highly path-dependent and institutions differ tremendously and systematically among countries (Djankov et al., 2003). Some African countries' institutional framework is significantly weaker than other developing countries, representing particular challenges for MNEs. They often have poor regulatory systems, flawed judiciaries and unstable political systems that are still in the process of consolidation (Luiz and Stewart, 2014). For instance, Africa's regional susceptibility to war index is $26.3 \%$, compared to 19.4\% for Asia and 9.9\% for the Western Hemisphere (Reinhart and Rogoff, 2003) and Africa's regional average score of Corruption Perception Index is 3.2 out of 10 (with 1 being highly corrupt) compared to 4.4 for Asia and 6.6 for Western Europe (Transparency International, 2018), which indicate that the region is amongst the most politically unstable and corrupt worldwide. These institutional differences in comparison to other countries and their consequences for economic performance are of interest. Therefore, we need to rely on comparative information to understand how institutions affect MNEs differently across countries. This comparative institutional perspective that draws from comparative institutional analysis (Greif, 1998; Aoki and Rothwell, 2013) is employed by this study.

The comparative institution-based view of CBMAs shows that institutions regulatory or belief systems can underpin locational attractiveness of certain host countries and more importantly are situationally different across societies (see Dunning and Lundan, 2008 pp.137140). For African countries, their colonial history and ethno-linguistic fractionalization related sociopolitical instability create unique institutional contexts, which make them distinctive from 
most other emerging markets (Ellis et al., 2018). In this regard, based on the widespread perception that Africa is structurally and institutionally different from the rest of the developing world and also confirmed by several studies that there is a differential impact of FDI in Africa (Asiedu, 2006), we argue that African economies will have a distinct effect on the level of Chinese CBMAs. Evidence shows that Africa receives significantly less FDI than other developing regions (Asiedu, 2002; World Bank, 2014) and the fact that Africa has been relatively unsuccessful in attracting CBMAs compared to other developing regions (shown in Figure 1). In a similar vein we expect that an African country will be a less attractive destination for CBMAs compared to developing countries from other regions. Thus, we posit that:

Hypothesis 1a: Broadly speaking, Africa is less attractive to Chinese CBMA compared to other developing regions.

\section{*** FIGURE 1 ABOUT HERE ***}

A stable institutional environment should have a positive impact on CBMA investment. In this optic, clear laws and legal enforceability reduce costs related to information asymmetry and help investors pursue a cross-border deal (Dacin et al., 2002; Buckley et al., 2007). On the contrary, a weak institutional setting will be a deterrent to CBMAs, leading to a withdrawal of those investments (Asiedu and Villamil, 2000). However, in the case of China, Deng and Yang (2015) and Yang and Deng (2017) identify a negative effect of government effectiveness on the number

of Chinese CBMAs, meaning the higher the effectiveness of government of a host country, the lower the number of Chinese CBMAs in such country. Similarly, Malhotra et al. (2010) observe a significantly positive relationship between the value of Chinese CBMAs and the level of perceived corruption in the target country. The explanation why emerging markets MNEs may invest in countries with weak institutions is twofold.

First, companies that face a similar weak institutional environment at home, where there is an 'institutional void' (near absence of proper or lagging institutional rules), are well-equipped to invest in developing economies with similarly weak institutions (Chen et al., 2018). Secondly, developed economies firms avoiding countries with a weak institutional setting implies less competition for emerging markets MNEs to invest in these countries (Cheung et al., 2012). Thereby, we speculate that Chinese MNEs may be able and prefer to invest in developing countries with weak institutions. With regards to African countries, given the region's weaker institutional 
environment, a negative institutions-CBMAs link may be expected. However, Rogmans and Ebbers (2013) find an insignificant and negative association of business environmental risk with FDI in Africa, suggesting that investors are not deterred by Africa's overall risk levels.

There is, however, evidence contrary to this. Asiedu (2006) finds that an efficient legal system, less corruption and higher political stability promote FDI in Africa. Similarly, Wahid et al. (2009) also find that institutions, as political stability, shows up as a significant driver of FDI in Africa. In the case of Chinese FDI in Africa, Mourao (2017) finds that government effectiveness, control of corruption, political stability and regulatory quality all positively affect the efficiency of Chinese OFDI in Africa. One explanation as to why we may expect that Chinese multinational investment not to be completely insensitive to the institutional environment in a host economy has to do with the idea that investors can bear risks up to a certain threshold level, beyond which weak institutions become far too risky and hence a deterrent (Rogmans and Ebbers, 2013). This is in line with Aleksynska and Havrylchyk's (2013) finding that institutions can be a driving force when emerging MNEs invest in host countries with better institutions, while in countries with weak institutions they become a deterrent for FDI. Indeed, given this institutional deterrent effect, the Chinese government has encouraged domestic corporations to establish partnerships when venturing in Africa. At a more macro level, economic cooperation with African economies through the triennial 'Forum on China-Africa Cooperation' (FOCAC) serves to reaffirm Sino-African economic ties and hence provide 'insurance' against political risk (Dupasquier and Osakwe, 2006). However, the promotion capacity of Chinese trade with Africa by the state is limited, as the more China liberalizes, the more difficult it becomes to execute state control over private firms venturing abroad (Taylor, 2012).

Institutional reform in some African countries has lagged behind other developing nations (Dupasquier and Osakwe, 2006), particularly inadequate contract enforcement and widespread corruption (Ellis et al., 2015), putting Sino-African economic links at risk. Chinese investor's tolerance for risk, as argued above, has a limit. 'Continued' poor and weak institutional governance (in Africa) is expected to have a larger deterrent effect on Chinese investment. We argue that this deterrent effect applies to any institutionally weak developing state. Strong institutions may or may not positively affect inbound investment in a developing country, yet we do expect and hypothesize that the influence to be relatively positive for Africa (given the current state of its institutional setting). Thus it is hypothesized that: 
Hypothesis 1b: A developing country's institutions may be insensitive (positively related) to the number of Chinese CBMAs in that country.

Hypothesis 1c: An African country's institutions will have a larger (positive) influence (than in non-African developing economies) on the number of Chinese CBMAs in that country.

\subsection{Motivation to seek markets}

As an establishment mode compared to greenfield investment, CBMA allows MNEs to have greater control over international markets. This is because takeovers provide stable availability of products to consumers (Buckley et al., 2007; Davis and Cobb, 2010). Another reason firms might venture abroad is that they face a limit in their domestic market. So faced with this constraining domestic market and willingness for foreign market access, a market seeking motive will drive the multinational to engage in CBMA. The rationale behind the market seeking motive is driven by scale economies. The larger the host country market, one would expect the higher the degree of scale economies in distribution and production (Wang et al., 2012).

In the case of China, market constraints at home have propelled Chinese firms to go abroad. Indeed, since the domestic market has become increasingly constraining after several decades of hyper economic growth, competition in all domestic industries is enormous (Rui and Yip, 2008). Hence, these market constraints at home may lead Chinese MNEs into CBMAs due to a market seeking motive. Furthermore, fierce competition between powerful global rivals from advanced markets, also acts as a push factor for EMNEs (Luo and Tung, 2007). Add to that the widespread belief that Chinese products have immense value for developing economies where consumers are more receptive to inexpensive goods produced by Chinese manufacturers than for products from advanced economies (Taylor, 2012). As there is relatively low competition in developing countries, market share growth potential for Chinese firms can be enormous. In short, intense competition faced by Chinese firms not only from foreign MNEs but also domestically emboldens them to move abroad. Empirically, Buckley et al. (2007), Deng and Yang (2015), Yang and Deng (2017) find that market size of host countries positively influences OFDI including CBMAs from China. This holds for both developed and developing economies.

When it comes to Africa, market size is also found to be positively important for Chinese OFDI (Cheung et al., 2012). As such, larger African markets are attractive for Chinese CBMAs. From a comparative perspective, however, given that domestic markets for many African countries 
are relatively small and market attractiveness of some African economies would be lagging behind developing countries in other regions (Taylor, 2009), we would expect the market seeking motive to be less relevant in Africa compared to elsewhere.

Henceforth, we expect market size of developing countries, including African ones, to facilitate the number of CBMAs by Chinese companies, which leads to the following hypotheses (absolute and relative respectively):

Hypothesis 2a: A developing country's market size will have a positive effect on the number of Chinese CBMAs in that country.

Hypothesis 2b: An African country's market size will have a lesser influence (than in non-African developing economies) on the number of Chinese CBMAs in that country.

\subsection{Motivation to seek natural resources}

According to the OLI paradigm and viewing the situation from a resource-based perspective, multinational firms who are or are planning to operate abroad rely on heterogeneous resources. In particular, natural resources such as minerals, natural gas, crude oil and timber are all seen as important to a firm's development. MNEs may venture abroad to acquire a widely diversified set of resources where they obtain control of such core resources. Chinese MNEs, faced with increased prices for imported raw materials in China and increasingly saturated export markets have felt compelled to obtain their own sources of raw materials abroad (Taylor, 2012).

In this optic, the abundance of natural resources in Africa would lead to even more Chinese CBMAs aggressively pursuing these raw materials. These deals are largely supported by the central government as continued access to various raw materials and energy can sustain China's economic growth (Ellis et al., 2015). Biggeri and Sanfilippo (2009) find natural resources as one of the key pull factors of Chinese FDI into Africa, a finding supported by Mourao (2017). Since natural resources is one comparative advantage of the region and 24 African countries are classified by the World Bank as oil- and mineral-dependent, which accounted for three-quarters of annual FDI inflows over the past two decades (Wahid et al., 2009; World Bank, 2014), we expect resource-rich Africa to be relatively more attractive than other developing economies. Apart from the 'resource-rich' explanation, investing in other developing economies could be due to other 'balanced' motives, such as the hypothesized market-seeking motive. In the absence of a marketseeking orientation towards Africa among Chinese companies, this leaves the resource-seeking 
motive as the preeminent reason for investing in Africa. Accordingly, we propose that Chinese MNEs will increase the number of CBMAs in host developing countries, but more so in African countries. Therefore:

Hypothesis 3a: A developing country's natural resources will have a positive effect on the number of Chinese CBMAs in that country.

Hypothesis 3b: An African country's natural resources will have a larger influence (than in nonAfrican developing economies) on the number of Chinese CBMAs in that country.

\subsection{Motivation to seek strategic assets}

Chinese MNEs are prompted to extensively conduct aggressive outbound acquisitions to seek foreign strategic assets because of the paucity of sufficient ownership advantages or competitive advantages in China (Deng, 2009; Rui and Yip, 2008; Liu and Woywode, 2013). Strategic assets including brand names, patents and advanced technologies, and managerial expertise are pursued by Chinese MNEs to reduce their late-comer disadvantages (Cui et al., 2014). This is exemplified by TCL's acquisition of Thompson to obtain the latter's proprietary technology and trademarks. Similarly, Luo and Tung (2007) view Chinese CBMAs as a springboard to acquire strategic assets, including technological leadership, global consumer base and high brand recognition. Boateng et al. (2008) examine 27 Chinese outbound M\&A transactions from 2000 to 2004 based on listed motivations in company annual reports. They find that among the primary motives for such outbound M\&As are strategic assets, such as technology and management know-how.

While we expect strategic assets to be a main driving force of Chinese CBMAs, Africa is less likely to attract such strategic asset-seeking CBMAs. In general, multinational corporations possess superior intangible assets including technology than African local firms and this gap of technological endowments induces African countries to attract FDI to achieve technology spillovers or transfers (Bwalya, 2006, Managi and Bwalya, 2010; Oguji et al., 2018). Therefore, we posit that:

Hypothesis 4a: A developing country's strategic assets will have a positive effect on the number of Chinese CBMAs in that country.

Hypothesis 4b: An African country's strategic assets will have a lesser influence (than in nonAfrican developing economies) on the number of Chinese CBMAs in that country. 


\subsection{Motivation to seek efficiency}

While lacking conventional ownership advantages, Chinese firms enjoy several home country advantages such as low labor costs and sometimes high labor productivity (Bhaumik et al., 2016). An enormous home market and demand base enable Chinese MNEs to leverage competitive advantages derived from economies of scale and improve production efficiency. However, this notwithstanding, internationalized Chinese MNEs could benefit more from economies of scale than local firms. This is because expanding abroad allows these emerging-economy MNEs to attain a larger market which enables them to exploit economies of scale and thus improve efficiency (Chari and Shaikh, 2017). For instance, by analyzing Chinese firm-level data in the electronics industry from 2005 to 2009, Bhaumik et al. (2016) contend that scale efficiency contributed more to the growth of Chinese firms than the traditional firm-specific advantages (FSAs). Thus, Chinese firms are motivated to seek efficiency and scale economies resulting from CBMAs. Basically, lower (higher) the labor costs (productivity), the higher the number of CBMA deals by Chinese MNEs.

While we do not expect Chinese firms to pursue CBMAs in developed countries for any efficiency-seeking motive, the situation is different in developing countries, as costs of labor and production are significantly lower than advanced economies, and these should generally magnify the impact of labor efficiency on Chinese CBMAs' location decisions.

Labor market efficiency, seen as low labor cost or high labor productivity, is expected to have a positive association with the number of Chinese CBMA deals in developing countries, which should have a magnifying effect in the African region. We hypothesize:

Hypothesis 5a: A developing country's labor efficiency will have a positive effect on the number of Chinese CBMAs in that country.

Hypothesis 5b: An African country's labor efficiency will have a larger influence (than in nonAfrican developing economies) on the number of Chinese CBMAs in that country.

\subsection{Establishment mode and ownership strategies}

Most of the paper so far describes hypothesized expected variation with respect to locational characteristics. We now turn to hypothesized variation regarding the dependent variable, which so 
far we have seen as (number of) CBMAs. This appears as a subset of the 'explained' factor in Figure 2.

\section{*** FIGURE 2 ABOUT HERE ***}

It is contended that M\&As are conducted for different reasons than greenfield investments. Greenfield investments rely on MNEs' internal capability to build a subsidiary from scratch, while CBMAs mainly lead to shifting control from domestic to foreign firms. Moreover, greenfield investment does not involve direct interactions with foreign partners but these interactions are crucial for CBMAs. Hence, given these differences, greenfield investments may be determined by different set of factors from CBMAs (Buckley et al., 2016). In particular, we expect locational factors to vary for these two establishment modes.

It is apparent that the strategic assets seeking motive is more likely to be an acquisition motive than a greenfield one (Dunning and Lundan, 2008). Similarly, the resource seeking motive could also be driven more by acquisitions. For instance, as highlighted above, the need for resource security has driven Chinese firms abroad to secure natural resources. As natural resources cannot be duplicated internally and their external purchase would be too costly, greenfield investment could be an inferior choice compared to acquisitions. Chen (2008) finds that procurements of complementary capability is more likely to be the major driver for choosing CBMAs over greenfield investments. Thus, we expect that acquisition of target firms embedded in host economies with strategic assets and natural resources is a more preferable entry mode than greenfield investment by Chinese MNEs.

To explore the ownership structure of Chinese CBMAs, we can classify CBMAs according to acquisition stakes. As part of their 'ownership strategies', acquiring firms can choose from 10\% to $50 \%$ equity in target firms, which provides them with 'voice only' rights, whilst they get 'voice and control' if they choose an ownership strategy of more than 50\% equity (Head, 2007). The former implies multinational investment in associates that gives them an active role but not a controlling interest, while the latter refers to having majority owned subsidiaries or affiliates with an effective managerial voice that comes with having a controlling interest (Ibid). Though somewhat related to the notion of 'entry strategies' of MNEs through partial or full acquisitions (Oguji and Owusu, 2017), the ownership strategies of 'voice and control' or 'voice only' differ in that partial deals could be minority-owned or majority-owned, with the former lacking control. 
Because voice and control of target firms provide MNEs with high initial resource commitments (Chari and Chang, 2009), Chinese MNEs predominantly seek more than 50\% stakes in target firms to gain access to critical resources through dominant ownership (Cui and Jiang, 2009, Contractor et al., 2014). To understand why these two concepts could matter, consider the example of Chinese automobile manufacturer Geely's dual acquisitions from Proton, the Malaysian car maker. One acquisition entailed a 49.9 per cent stake of Proton itself and the second was a 51 per cent stake of Proton's British-based subsidiary, Lotus (Financial Times, 2017). This interesting difference of more than 1 per cent stake exemplifies the concept of voice with and without control. Geely's aim was to seek sales channels in Southeast Asia which it could gain through partnership with a well-established brand in that market such as Proton. Thus, a minority stake with 'voice only' served its purpose well (to expand its market), given the guaranteed continued help from the former owners and now partners. On the contrary, Geely intended to deploy Lotus's composite materials and light-weighting technology to reduce its vehicles' emissions, which necessitated a majority stake of $51 \%$ with both 'voice and control' to gain greater resource access (Ibid).

In light of the above we hypothesize,

Hypothesis 6a: The location characteristics of host economies (developing or African) may differ in their effects dependent on whether the establishment mode is acquisition or greenfield.

Hypothesis 6b: The location characteristics of host economies (developing or African) may differ in their effects dependent on whether the acquisitions are majority-owned (voice \& control) or not (voice only).

\section{Data and methods}

The dependent variable in this study is the "number of CBMAs by Chinese MNEs in developing countries from 2007 to 2016, which is drawn from the Securities Data Company (SDC) Platinum provided by Thomson Financial. It was measured by the total number of complete Chinese CBMA deals in each developing country in each year, which created a panel data of country-year. We also divide the number of Chinese CBMAs into the number of deals with voice and control and with voice only. Though SDC Platinum is our preferred CBMA data source because of its extensive coverage, as an M\&A database it does not have information on greenfield investment. Therefore, the 'number of Chinese greenfield investments' is drawn from the Global Investment Tracker (GIT) 
database by the American Enterprise Institute and the Heritage Foundation. As the GIT dataset contains only large transactions worth over 100 million US dollars, for comparative purposes we also use the 'number of Chinese CBMAs' from the data source.

The definition of developing countries is drawn from the classifications by the World Bank, which includes all low income, lower-middle income and upper-middle income countries but excludes high-income economies. The reason why we use the number of CBMA transactions instead of CBMA value is twofold. Firstly, missing information on CBMA values in the SDC database reduces our sample significantly. Secondly, the value of deals can be extremely large or small, thus may distort the degree of CBMA involvement by Chinese MNEs. Therefore, the number of CBMAs is more appropriate for our study as we assign 1 evenly and equally to each transaction of each country every year regardless of their values. It is worthwhile mentioning that we set the number of deals in developing countries as defined by the World Bank that are not included in SDC databases as zero throughout the period of 2007-2016.

To explore the role of natural resources we draw information from the World Bank's World Development Indicators (WDI). The resource variable employed is total resource rents (as \% of GDP). The 'resource rents' variable is used as a proxy for natural resources because we assume that all natural resources including oil, natural gas and mineral are of interest to Chinese MNEs. The 'market size' variable is taken from the Global Competitiveness Report (GCR) of the World Economic Forum to proxy the market size of the host country. 'Patents' applications by residents (the number of patents in the host country) taken from the WDI is the proxy for strategic assets of host countries.

We use output per worker (GDP constant 2011 international \$ in PPP) taken from the International Labor Organization (ILO) database to represent 'labor productivity' and thus proxy labor efficiency.

The World Governance Indicators (WGI) database is used to proxy the governance-related institutional environment of a developing country. There are in total six indices of institutional governance; voice and accountability; political stability; government effectiveness; regulatory quality; rule of law; control of corruption. After analyzing each of the six proxies of institutions, finally, an overall measure of institutional governance, the six indices totaled, is adopted to proxy the overall institutional environment of a developing country. 
The effect of time is controlled for by a time trend variable. Controlling for a time effect is necessary for two principal reasons. First, there is a rising trend of Chinese CBMAs during the period (see Figure 1). Second, common time-specific factors affecting all economies alike could impinge on the decision to invest. For example, changes in the relative exchange rate can make it attractive for Chinese companies to invest in developing economies including in Africa, or there could be changes to the China-Africa relationship over time. Indeed, the China-Africa economic relationship has gradually improved over time due to the advent of the Forum on China-Africa Cooperation (FOCAC) (Taylor, 2012), and as a result one would expect the overseas acquisition strategy of Chinese companies may have reflected such changes.

In addition, 'Africa' is a dummy variable, which takes value 1 when the developing country is an African economy and 0 otherwise. This is used to test Hypothesis 1 . Five interactive terms Market size*Africa, Resources rents*Africa, Patents*Africa, Labor productivity*Africa and Institutions*Africa -and the Africa dummy variable are included to test Hypotheses 2b, 3b, 4b, 5b and $6 \mathrm{~b}$. These interactive terms measure the relative/differential effect of locational determinants on Chinese CBMAs in African countries. Because the dependent variable is the number of CBMAs in developing economies that are nonnegative integers and range from 0 to 7 , standard least squares regression is improper under the circumstance. Therefore, the Poisson model and negative binomial model are considered to deal with the count nature of the data. However, the Poisson model makes a strong assumption that the mean and variance are the same. This may be unrealistic for our data and in many situations this may not be the case. As the negative binomial model adjusts the variance independently from the mean, we adopt this model.

As our data is a set of longitudinal panel data containing repeated observations across years, our analysis can be subjected to biases related to lack of independence and unobserved heterogeneity that may lead to underestimation of the true standard error. To address these issues, we employed a random-effects negative binomial model. In addition, we take one-year lag of market size, resources rents, patents, labor productivity, and institutions to avoid possible endogeneity issue.

The variables are in natural logarithm which reduces extreme variability and allows for more interpretable coefficients in terms of percent change. We study five locational determinants of Chinese CBMAs in developing countries, namely market size, resources rents, patents, labor productivity, and institutions, with a particular interest on examining whether there are differential 
effects of these five locational determinants on African countries compared to other developing counterparts. In addition, these same locational factors are compared in their effects on CBMA with voice and control to voice only, and their effects between CBMA and greenfield investment.

\section{Results}

The correlation matrix and summary statistics of the variables are presented in Table 1 and Table 2 respectively. It can be seen that the variables are not highly correlated to each other, except for the correlation between market size and residents' patents (0.72). We report our findings with these two variables both together and separately in our regression models.

\section{*** TABLE 1 ABOUT HERE *** *** TABLE 2 ABOUT HERE ***}

Tables 3, 4, 5 and 6 report the regression results of the panel negative binomial estimation. In all tables, Model 1 accounts for market size in Africa by incorporating the interactive term market size multiplied by Africa; similarly, model 2 to model 5 account for natural resources, strategic assets, labor productivity and institutions in Africa respectively by incorporating interactive terms with the Africa dummy variable. As indicated earlier, we also run these regressions with market size and patents both together and separately. The only noticeable effect is on the market size variable (see Appendix 1). Tables 3 and 6 use CBMA data from SDC Platinum for estimation, while Tables 4 and 5 report the results for greenfield investment and CBMAs based on the Global Investment Tracker dataset (the latter to have a comparison between entry mode when one information source is used). Table 6 presents the results for interactive African dummies according to two dependent variables; the number of Chinese CBMAs with voice and control and the number of Chinese CBMAs with voice only. It can be noted that regression models fit well with the data as the Wald $\chi^{2}$ are all significant at $1 \%$ level of significance and the Pseudo $\mathrm{R}^{2}$ range from $7 \%$ to $8 \%$, which appear reasonable compared to other CBMAs studies.

Our interpretation for support (or not) of hypothesis H1a should be based not just on the Africa dummy variable but also the interactive dummies in each regression. This is because the sign of the Africa dummy is both positive and negative (which does not necessarily make this more or less attractive). The inference is, although Africa is 'generally' speaking an unattractive destination because of its institutional lacunae, including unfavorable market conditions, certain 'specific' characteristics (such as natural resources) make it attractive. 
*** TABLE 3 ABOUT HERE ***

Turning to the variables in level form and whether there is support for developing countries' market, resources, strategic assets, labor efficiency and institutions having generally a positive association with Chinese CBMAs, we find weak support for the market-seeking hypothesis $\mathrm{H} 2 \mathrm{a}$ or some support when we consider large investments only (Table 3 vs. Tables 4 and 5). Instead, the strong support for resource-seeking hypothesis H3a is limited to CBMAs only (Tables 3 \& 5 vs. Table 4), and strategic assets seeking hypothesis $\mathrm{H} 4 \mathrm{a}$ is supported across regressions irrespective of establishment mode or size of investment. We do not find support for the efficiencyseeking hypothesis H5a. In short, there is evidence to the effect that Chinese firms are attracted to the developing world by markets and resources (conditional on investment size and establishment mode), attracted to endowment of strategic assets, but not the efficiency-seeking motive.

\section{*** TABLE 4 ABOUT HERE *** *** TABLE 5 ABOUT HERE ***}

So some of these findings correspond to our expectations and are in line with previous empirical studies (Buckley et al., 2007, Kolstad and Wiig, 2012, Yang and Deng, 2017). The fact that labor efficiency is negatively signed can be rationalized by the fact that Chinese firms may have already achieved efficiency at home and as such this factor does not play as much of a role.

It is with respect to hypothesis $\mathrm{H} 1 \mathrm{~b}$ that we find evidence contrary to what past studies have found. We stipulated an uncertain two-sided hypothesis, instead of a one-sided hypothesis. Thus, this is somewhat contrary to our Hypothesis $1 \mathrm{~b}$, as the influence is clearly positive and significant (only positive in Tables 4 \& 5). More concretely, the coefficients of all five models in Table 3 are positive and significant at $1 \%(\mathrm{p}<.001)$, but positively signed and insignificant for results in Tables 4 and 5. This means unlike past studies, we find that strong institutions matter in a positive manner for most Chinese acquisitions, except for large investors. The rationale being that large investors have the capability to navigate difficult institutional terrain, with the explanation of difference with past studies being due to our focus on 'number of deals' rather than the 'value amount of investment'.

Moving to our central question: is Africa unique and different when it comes to attracting Chinese CBMAs? Here we need to look at all interactive terms with the Africa dummy variable. According to result in Model 1 of Table 3, Hypothesis $2 b$ is somewhat supported, such that the market-seeking motive is of lesser relevance in Africa vis-à-vis its other developing counterparts. 
This effect is more pronounced when we consider Model 1 without the strategic assets variable, namely Patents, with which it is correlated (see Appendix table). This means that Africa's market size is less effective in attracting Chinese CBMAs, and the market size of non-African developing countries will generate more Chinese CBMAs than that of Africa. One possible interpretation is that Africa's market is fragmented and lacks regionalism of a single market that is large enough to attract Chinese CBMAs (Asiedu, 2006).

With regards to natural resources, Table 1 shows a positive and weak differential effect on the interactive term of total resources and Africa $(\mathrm{p}<.1)$. This would seem to suggest there is only weak evidence of a differential effect for natural resources in Africa. However, according to Tables 4 and 5, Chinese CBMAs are significantly driven by developing countries' natural resources while this resource-seeking motive is less relevant for Chinese greenfield investments. More significantly, natural resources in African countries attract more Chinese CBMAs than in other developing countries, which suggests Chinese CBMAs' explicit and pronounced intention to procure Africa's natural resources. This supports our expectation that resources in Africa are mainly pursued by Chinese MNEs CBMAs rather than greenfield investments (Hypothesis 6a).

\section{*** TABLE 6 ABOUT HERE ***}

Furthermore, according to Table 6 (Panel A), Africa's natural resources significantly drive Chinese CBMAs with voice and control $(\mathrm{p}<.01)$, but this positive effect is absent for CBMAs with voice only (Panel B). Thus, there is some support for Hypothesis 6b. To be precise, we find that Africa's natural resources propel the CBMAs with majority stakes, which indicates Chinese MNEs' predominant preference for majority ownership and control over acquired African natural resources.

Though this seems in line with past findings that China's investment in Africa is primarily motivated by natural resources (Frynas and Paulo, 2006), this needs to be interpreted in the comparative context where this inference is drawn and that there is the added point of ownership with control. Indeed, our study is casting a comparative lens between African and developing economies. This finding shows that Chinese investors' strategy to obtain strategic resources is conducted via acquisitions (rather than greenfield) and this motive is more pronounced if they are with 'controlling interests'. The effects of interactive terms of institutions, strategic assets and labor productivity are all insignificant, with no support for Hypotheses 1c, 4b and 5b. This implies that Chinese investors treat African and non-African developing regions alike as far as strategic 
assets, labor efficiency and institutions are concerned. As such, Africa is not different in terms of these locational factors, but are significantly different in terms markets and resources.

Chinese MNEs are less market seeking in Africa and mostly enter via CBMAs rather than greenfield investments by majority ownership to exercise control on natural resources. We interpret this as supportive evidence in favor of our central proposition that Africa is uniquely different from its counterparts.

\section{Conclusion}

\subsection{Summary}

This study has investigated host country determinants of Chinese CBMAs in developing countries and the differential effect of Africa on such CBMA deals over the 2007-2016 period. Drawing from a comparative institution-based view, it studies the role market size, natural resources, strategic assets, labor efficiency, and institutions have on the number of Chinese CBMAs in developing economies (including Africa). One contribution of this study is at the intersection of two streams of the literature: Chinese CBMAs and CBMAs in Africa - with emphasis on providing a comparative perspective between African and other developing economies. As such this paper contributed to an extension of the current literature by shedding light on our understanding of Chinese multinational CBMAs in the developing world (comparatively with Africa).

Our study shows that a large market, available strategic assets, adequate natural resources, and strong institutions matter for Chinese multinational acquisitions in the developing world, but labor efficiency does not. The hypothesized 'distinctive' effect of Africa compared to other developing countries is shown to be present only for the market-seeking and resource-seeking motives. With respect to the African market, Chinese acquisitions appear to be relatively less drawn to Africa by a market seeking motive.

Yet when it comes to natural resources we see Chinese investors develop an investment strategy' that is Africa-specific. This strategy entails using M\&A as the mode of entry instead of greenfield investment in the process of acquiring natural resources. In addition, this CBMA is conducted through majority-ownership (voice \& control), as opposed to having voice in management only, to enable greater controlling interests over acquired natural resources. The inference is that Chinese MNEs view Africa as 'significantly' distinct due to its abundant raw materials. This finding contributes to our understanding of how Chinese MNEs conduct their 
acquisitions in the developing world and how they treat Africa differently, especially when it comes to the resource-seeking motive.

This implication of a strategy of majority ownership over African firms to secure access to African resources may compound the 'resource curse' problem that has plagued Africa. For instance, Africa's under-industrialized energy industries are vulnerable to negative price shocks

resulting from Chinese involvement, which deepens Africa's dependency on energy and may hamper industry diversification and broad economic prosperity (Leonard and Straus, 2003; Taylor, 2009). The potential issue of a resource curse sounds out a cautionary note to the endeavor of Chinese CBMAs in Africa. Currently, Chinese CBMAs have been unbalanced in China's favor and African governments should become more engaged in Sino-Africa economic ties such as taking advantage of China's Belt and Road Initiative (BRI), especially in infrastructure sectors, and regulate Sino-African energy policy to improve governance of natural resources in Chinese CBMAs (Du and Zhang, 2018).

The finding of CBMA being different to greenfield investment, especially for the resourceseeking motive, adds to our understanding that it may be problematic to investigate Chinese OFDI as a whole, given the motives of greenfield and CBMAs do differ. While extant studies largely investigate Chinese OFDI as a whole, our evidence shows these two entry strategies are different particularly in developing economies.

\subsection{Theoretical implications}

We have used a comparative institutional analysis grounded in a comparative institution-based view. Our work provides theoretical insights to better understand FDI location choice. Extant FDI theories document the role of location characteristics in determining investment choices of MNEs (Dunning and Lundan, 2008). This study suggests these locational factors 'comparatively' bear on such investment decision. This reflects investors' selection processes in location choices. Market seeking FDI, for example, is not only guided by the host economy's market size or potential, but the latter's market 'relative' to other potential hosts.

Our results suggest that it is imperative to analyze CBMA in Africa from a comparative institution-based view. Only comparing antecedents of CBMAs in Africa relative to the ones in other developing economies can answer the questions whether and how different African countries are in attracting foreign acquisitions. For instance, without comparisons between African 
economies and developing economies in other regions, studies reach the conclusion that Chinese investment into Africa is driven by natural resources and that is irrespective of the weak institutional setting of the continent (Rogmans and Ebbers, 2013). However, comparative characteristics of Africa enable us to challenge this viewpoint, as strong institutional governance mattered both for African and non-African economies although Chinese investors are not especially deterred by weak institutions of Africa. This aligns with the view of a few scholars who contend the same (Brautigam, 2009; Chen et al., 2018). Therefore, a comparative institution-based view helps us to identify the underlying distinct antecedents of Chinese CBMAs in Africa, which is also urged by previous studies on Chinese CBMA's calling for more comparative studies on cross-border M\&As (Aybar and Ficici, 2009; Nicholson and Salaber, 2013).

\subsection{Managerial implications}

From an international business perspective, this study shows some key factors in acquiring firms in developing countries. Hence, Chinese firms may regard these factors as indicators for crossborder investment opportunities. This study is informative with regard the foreign entry strategies of emerging market MNEs for acquisitions in the developing world. It shows how such foreign entry strategies (including establishment modes) are moderated by the 'distinctiveness' of the host and the interplay with the ownership strategies of the MNEs. The acquisition of strategic resources is motivated by the need to control access to said resources. Furthermore, attractiveness in investing in developing hosts lies in having large markets, marketable natural resources and strategic assets, and strong institutional governance.

\subsection{Limitations and future research directions}

Some limitations of this effort must be recognized. Firstly, given the homogenous characteristics of each African region, sub-sample analysis of Sub-Saharan African countries, Northern African countries and other subgroups could be meaningful. Secondly, it is worthwhile comparing different impacts of locational determinants on the number and value of CBMAs. Finally, future research may also incorporate home country motives of CBMAs, in particular, home countries' institutional settings can be studied together with host countries' institutional determinants. 


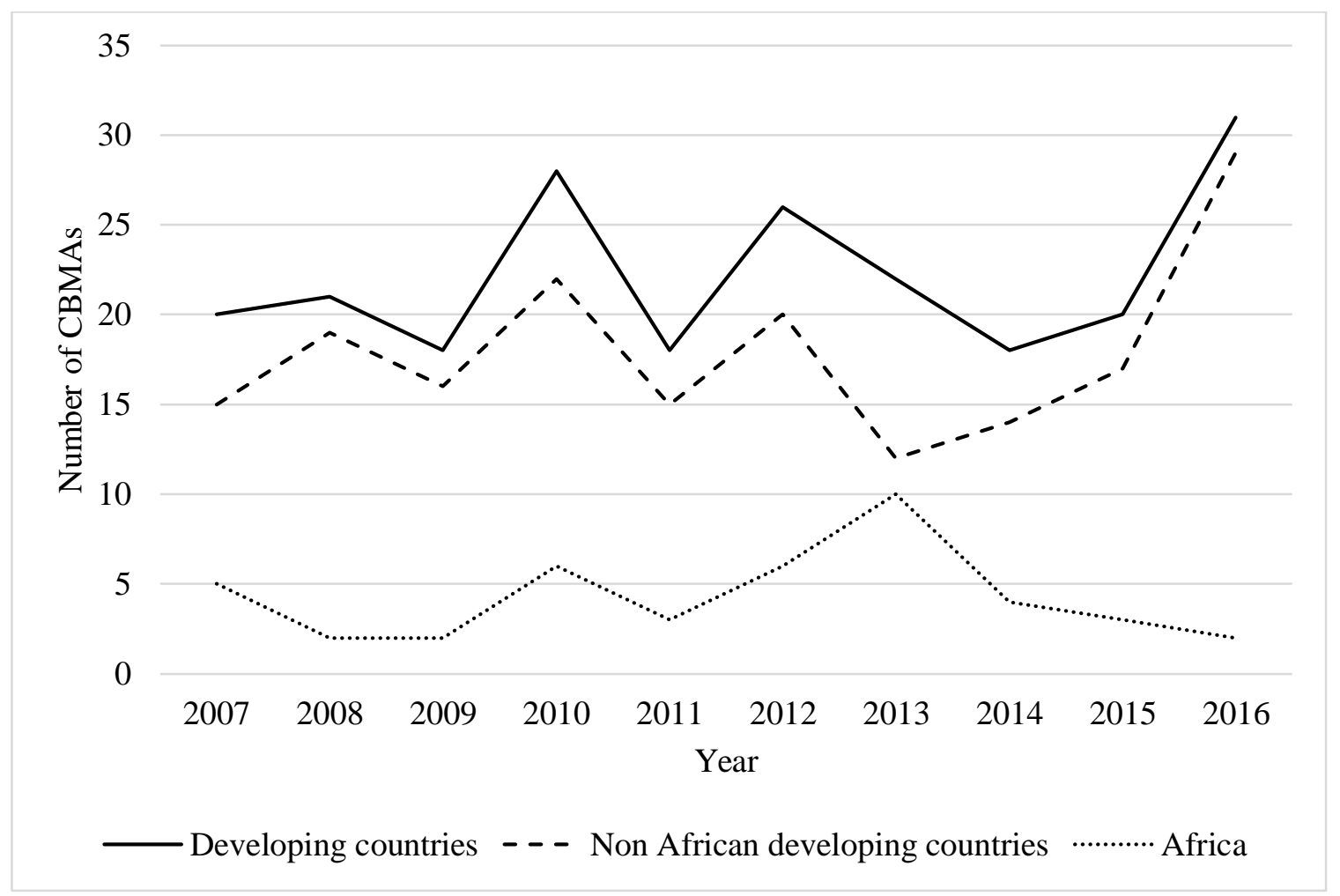

Figure 1. Number of Chinese CBMAs from 2007 to 2016

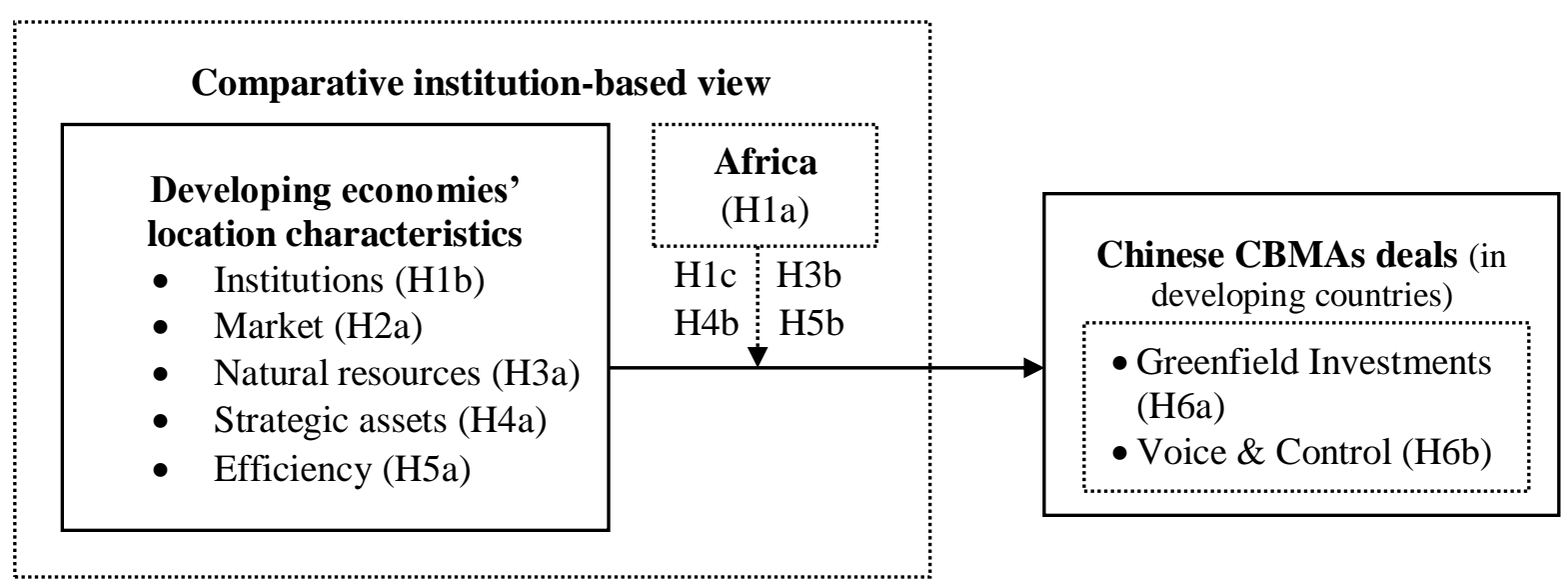

Figure 2. Theoretical framework of Chinese CBMAs in the Developing World 
Table 1. Correlation matrix

\begin{tabular}{lllllll}
\hline & \multicolumn{1}{c}{1} & 2 & 3 & 4 & 5 & 6 \\
\hline 1. No. of CBMAs & 1.00 & & & & & \\
2. Market size & $0.29^{* * *}$ & 1.00 & & & & \\
3. Resources rents & $0.06^{*}$ & $-0.07^{* *}$ & 1.00 & & & \\
4. Patents & $0.38^{* * *}$ & $0.72^{* * *}$ & $-0.14^{* * *}$ & 1.00 & & \\
5. Labor productivity & $0.17^{* * * *}$ & $0.44^{* * *}$ & $-0.21^{* * *}$ & $0.48^{* * *}$ & 1.00 & \\
6. Institutions & $0.12^{* * *}$ & -0.03 & $-0.35^{* * *}$ & $0.12^{* * *}$ & $0.33^{* * *}$ & 1.00 \\
\hline
\end{tabular}

Note: $\mathrm{N}=855 .{ }^{* * *} \mathrm{p}<.01 ;{ }^{* *} \mathrm{p}<.05 ;{ }^{*} \mathrm{p}<.1$. All variables except dummies variables are in log form and lagged by one year.

Table 2. Descriptive Statistics

\begin{tabular}{lllll}
\hline Variables & Mean & SD & Max & Min \\
\hline No. of CBMAs & 0.24 & 0.74 & 6.00 & 0.00 \\
Market size & 1.12 & 0.38 & 1.83 & -1.12 \\
Resources rents & 1.54 & 1.67 & 4.10 & -6.77 \\
Patents & 3.07 & 2.69 & 10.28 & 0.00 \\
Labor productivity & 9.57 & 0.93 & 11.47 & 7.45 \\
Institutions & 5.37 & 1.28 & 8.08 & 0.96 \\
Resources rents * Africa & 0.85 & 1.44 & 4.10 & -6.77 \\
Patents * Africa & 0.66 & 1.51 & 6.82 & 0.00 \\
Labor productivity * Africa & 3.68 & 4.52 & 11.47 & 0.00 \\
Institutions * Africa & 2.12 & 2.72 & 8.08 & 0.00 \\
\hline
\end{tabular}


Table 3. Panel Negative Binomial Results for the Number of Chinese CBMAs

\begin{tabular}{|c|c|c|c|c|c|}
\hline & Deper & dent Varia & ble: No. of & Chinese C & $\overline{B M A s}$ \\
\hline & Model 1 & Model 2 & Model 3 & Model 4 & Model 5 \\
\hline Time trend & 0.026 & 0.030 & 0.026 & 0.030 & 0.028 \\
\hline & $(0.03)$ & $(0.03)$ & $(0.03)$ & $(0.03)$ & $(0.03)$ \\
\hline Africa & $2.306^{*}$ & $-1.653^{*}$ & 0.195 & -3.065 & -0.386 \\
\hline & $(1.22)$ & $(0.89)$ & $(0.59)$ & (3.20) & $(1.47)$ \\
\hline Market size & $2.009^{* *}$ & $1.182^{*}$ & $1.208^{*}$ & $1.129^{*}$ & $1.219^{*}$ \\
\hline & $(0.79)$ & $(0.66)$ & $(0.68)$ & $(0.67)$ & $(0.68)$ \\
\hline Resources rents & $0.381^{* * *}$ & $0.324^{* *}$ & $0.373^{* * *}$ & $0.410^{* * *}$ & $0.393^{* * *}$ \\
\hline & $(0.13)$ & $(0.13)$ & $(0.13)$ & $(0.13)$ & $(0.13)$ \\
\hline Patents & $0.286^{* * *}$ & $0.343^{* * *}$ & $0.347^{* * *}$ & $0.333^{* * *}$ & $0.318^{* * * *}$ \\
\hline & $(0.09)$ & $(0.08)$ & $(0.09)$ & $(0.09)$ & $(0.08)$ \\
\hline Labor productivity & -0.215 & $-0.382^{* *}$ & -0.322 & $-0.529^{* *}$ & $-0.363^{*}$ \\
\hline & $(0.21)$ & $(0.19)$ & $(0.20)$ & $(0.27)$ & $(0.20)$ \\
\hline Institutions & $0.459^{* * *}$ & $0.505^{* * *}$ & $0.458^{* * * *}$ & $0.483^{* * *}$ & $0.458^{* * *}$ \\
\hline & $(0.14)$ & $(0.14)$ & $(0.14)$ & $(0.14)$ & $(0.16)$ \\
\hline Market size $*$ Africa & $-2.024^{* *}$ & & & & \\
\hline & $(0.93)$ & & & & \\
\hline Resources rents $*$ Africa & & $0.631^{*}$ & & & \\
\hline & & $(0.36)$ & & & \\
\hline Patents $*$ Africa & & & -0.112 & & \\
\hline & & & $(0.12)$ & & \\
\hline Labor productivity $*$ Africa & & & & 0.287 & \\
\hline & & & & $(0.33)$ & \\
\hline Institutions $*$ Africa & & & & & 0.022 \\
\hline & & & & & $(0.25)$ \\
\hline Constant & $-5.766^{* * *}$ & $-3.473^{*}$ & $-3.880^{* *}$ & -1.879 & $-3.385^{*}$ \\
\hline & $(2.17)$ & $(1.84)$ & $(1.94)$ & $(2.58)$ & $(1.97)$ \\
\hline Number of observations & 855 & 855 & 855 & 855 & 855 \\
\hline Log Likelihood & -374.10 & -375.17 & -376.34 & -376.41 & -376.78 \\
\hline Pseudo $R^{2}$ & 0.076 & 0.073 & 0.070 & 0.070 & 0.069 \\
\hline Wald $\chi^{2}$ & $90.19^{* * *}$ & $88.66^{* * *}$ & $85.38^{* * *}$ & $87.57^{* * *}$ & $83.10^{* * *}$ \\
\hline
\end{tabular}




\section{Table 4. Results for the Number of Chinese CBMAs with Voice \& Control and with Voice only}

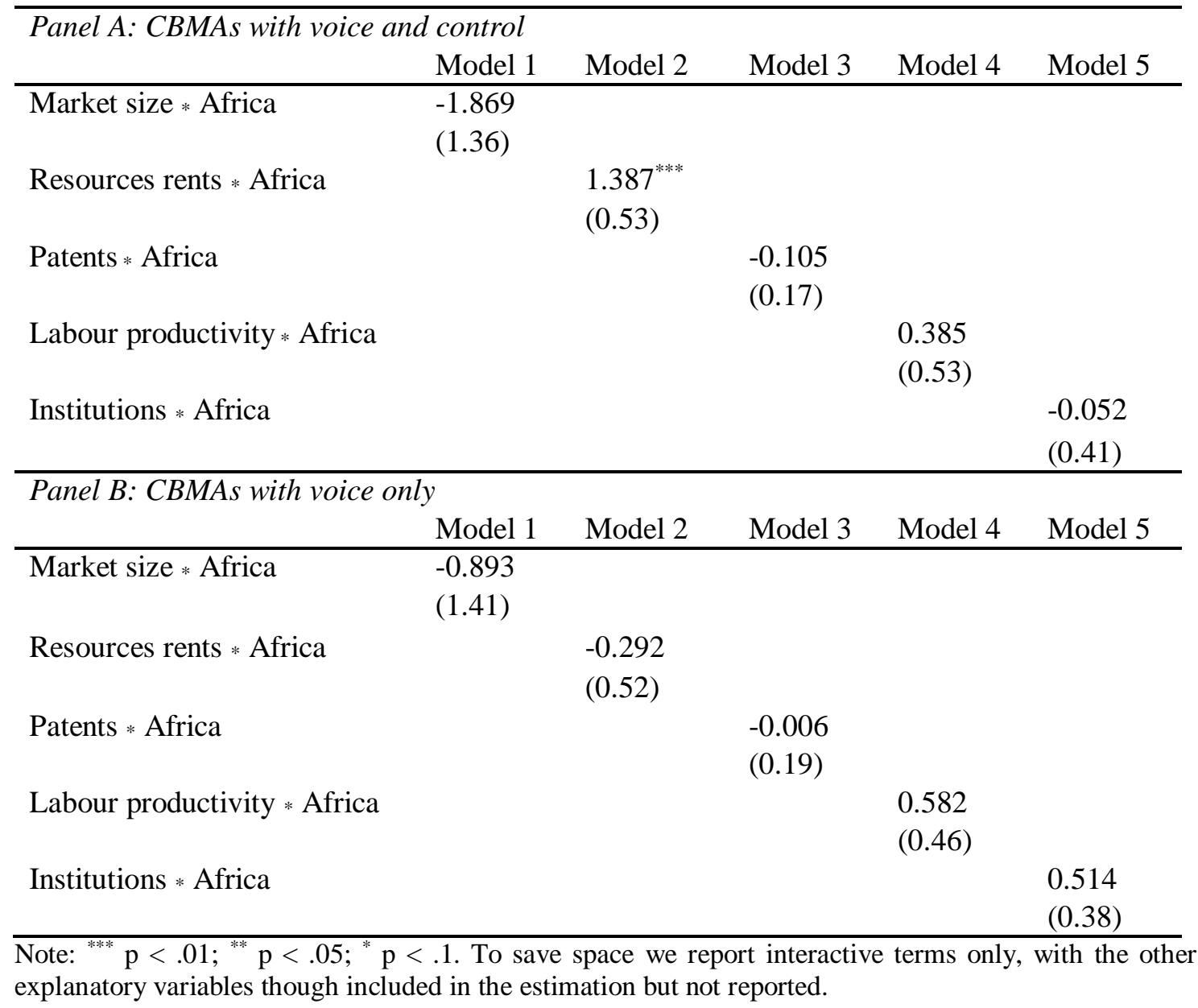


Table 5. Results for the Number of Chinese Greenfield Investments (using Global Investment Tracker)

\begin{tabular}{|c|c|c|c|c|c|}
\hline & \multicolumn{5}{|c|}{ Dependent Variable: No. of Chinese greenfield investments } \\
\hline & Model 1 & Model 2 & Model 3 & Model 4 & Model 5 \\
\hline \multirow[t]{2}{*}{ Time trend } & $0.134^{* * *}$ & $0.141^{* * *}$ & $0.136^{* * *}$ & $0.138^{* * *}$ & $0.136^{* * *}$ \\
\hline & $(0.03)$ & $(0.03)$ & $(0.03)$ & $(0.03)$ & $(0.03)$ \\
\hline \multirow[t]{2}{*}{ Africa } & $2.871^{* *}$ & 0.309 & 0.264 & -0.424 & 0.281 \\
\hline & $(1.26)$ & $(0.53)$ & $(0.53)$ & $(3.68)$ & $(1.21)$ \\
\hline \multirow[t]{2}{*}{ Market size } & $3.191^{* * *}$ & $1.807^{* * *}$ & $1.837^{* * *}$ & $1.784^{* *}$ & $1.842^{* * *}$ \\
\hline & $(0.89)$ & $(0.69)$ & $(0.69)$ & $(0.71)$ & $(0.70)$ \\
\hline \multirow[t]{2}{*}{ Resources rents } & 0.104 & 0.183 & 0.102 & 0.115 & 0.108 \\
\hline & $(0.10)$ & $(0.13)$ & $(0.11)$ & $(0.11)$ & $(0.11)$ \\
\hline \multirow[t]{2}{*}{ Patents } & $0.154^{*}$ & $0.226^{* * *}$ & $0.250^{* * *}$ & $0.224^{* *}$ & $0.214^{* *}$ \\
\hline & $(0.09)$ & $(0.09)$ & $(0.09)$ & $(0.09)$ & $(0.09)$ \\
\hline \multirow[t]{2}{*}{ Labor productivity } & $-0.557^{* *}$ & $-0.681^{* * *}$ & $-0.638^{* * *}$ & $-0.660^{* *}$ & $-0.637^{* * *}$ \\
\hline & $(0.22)$ & $(0.24)$ & $(0.23)$ & $(0.31)$ & $(0.23)$ \\
\hline \multirow[t]{2}{*}{ Institutions } & 0.081 & 0.053 & 0.056 & 0.066 & 0.090 \\
\hline & $(0.12)$ & $(0.12)$ & $(0.12)$ & $(0.12)$ & $(0.14)$ \\
\hline \multirow[t]{2}{*}{ Market size $*$ Africa } & $-2.463^{* *}$ & & & & \\
\hline & $(0.99)$ & & & & \\
\hline \multirow[t]{2}{*}{ Resources rents * Africa } & & -0.217 & & & \\
\hline & & $(0.21)$ & & & \\
\hline \multirow[t]{2}{*}{ Patents * Africa } & & & -0.121 & & \\
\hline & & & $(0.13)$ & & \\
\hline \multirow[t]{2}{*}{ Labor productivity $*$ Africa } & & & & 0.036 & \\
\hline & & & & $(0.39)$ & \\
\hline \multirow[t]{2}{*}{ Institutions $*$ Africa } & & & & & -0.070 \\
\hline & & & & & $(0.22)$ \\
\hline \multirow[t]{2}{*}{ Constant } & 14.648 & 15.040 & 18.496 & 15.663 & 15.165 \\
\hline & $(872.19)$ & $(625.02)$ & $(423.17)$ & $(637.09)$ & $(765.56)$ \\
\hline Number of observations & 855 & 855 & 855 & 855 & 855 \\
\hline Log likelihood & -399.686 & -402.21 & -402.291 & -402.716 & -402.67 \\
\hline Pseudo $R^{2}$ & 0.115 & 0.110 & 0.109 & 0.108 & 0.109 \\
\hline Wald $\chi^{2}$ & $64.92^{* * *}$ & $60.69^{* * *}$ & $60.3^{* * *}$ & $59.78^{* * *}$ & $59.93^{* * * *}$ \\
\hline
\end{tabular}

Note: ${ }^{* * *} \mathrm{p}<.01 ;{ }^{* *} \mathrm{p}<.05 ;{ }^{*} \mathrm{p}<.1$. Robust standard errors are in parentheses. 
Table 6. Results for the Number of Chinese CBMAs (using Global Investment Tracker)

\begin{tabular}{|c|c|c|c|c|c|}
\hline & \multicolumn{5}{|c|}{ Dependent Variable: No. of Chinese CBMAs } \\
\hline & Model 1 & Model 2 & Model 3 & Model 4 & Model 5 \\
\hline \multirow[t]{2}{*}{ Time trend } & $0.135^{* * *}$ & $0.141^{* * *}$ & $0.134^{* * *}$ & $0.134^{* * *}$ & $0.137^{* * *}$ \\
\hline & $(0.04)$ & $(0.04)$ & $(0.04)$ & $(0.04)$ & $(0.04)$ \\
\hline \multirow[t]{2}{*}{ Africa } & 2.233 & $-1.954^{* *}$ & 0.503 & 2.772 & 0.520 \\
\hline & $(1.40)$ & $(0.99)$ & $(0.62)$ & $(4.10)$ & $(1.29)$ \\
\hline \multirow[t]{2}{*}{ Market size } & $2.722^{* * *}$ & $1.780^{* *}$ & $1.804^{* *}$ & $1.974^{* *}$ & $1.880^{* *}$ \\
\hline & $(0.93)$ & $(0.76)$ & $(0.77)$ & $(0.80)$ & $(0.78)$ \\
\hline \multirow[t]{2}{*}{ Resources rents } & $0.374^{* * *}$ & $0.285^{* *}$ & $0.344^{* *}$ & $0.370^{* * *}$ & $0.381^{* * *}$ \\
\hline & $(0.14)$ & $(0.14)$ & $(0.14)$ & $(0.14)$ & $(0.14)$ \\
\hline \multirow[t]{2}{*}{ Patents } & $0.179^{*}$ & $0.262^{* * * *}$ & $0.284^{* * *}$ & $0.207^{* *}$ & $0.224^{* *}$ \\
\hline & $(0.10)$ & $(0.09)$ & $(0.10)$ & $(0.10)$ & $(0.09)$ \\
\hline \multirow[t]{2}{*}{ Labor productivity } & -0.155 & -0.333 & -0.243 & -0.125 & -0.316 \\
\hline & $(0.26)$ & $(0.24)$ & $(0.25)$ & $(0.36)$ & $(0.25)$ \\
\hline \multirow[t]{2}{*}{ Institutions } & 0.137 & 0.164 & 0.120 & 0.128 & 0.182 \\
\hline & $(0.12)$ & $(0.12)$ & $(0.12)$ & $(0.12)$ & $(0.14)$ \\
\hline \multirow[t]{2}{*}{ Market size $*$ Africa } & $-2.002^{*}$ & & & & \\
\hline & $(1.08)$ & & & & \\
\hline \multirow[t]{2}{*}{ Resources rents $*$ Africa } & & $0.751^{* *}$ & & & \\
\hline & & $(0.38)$ & & & \\
\hline \multirow[t]{2}{*}{ Patents * Africa } & & & $-0.224^{*}$ & & \\
\hline & & & $(0.13)$ & & \\
\hline \multirow[t]{2}{*}{ Labor productivity * Africa } & & & & -0.314 & \\
\hline & & & & $(0.42)$ & \\
\hline \multirow[t]{2}{*}{ Institutions $*$ Africa } & & & & & -0.150 \\
\hline & & & & & $(0.24)$ \\
\hline \multirow[t]{2}{*}{ Constant } & -4.249 & -1.549 & -2.606 & -3.497 & -1.893 \\
\hline & $(2.68)$ & $(2.27)$ & $(2.31)$ & $(3.50)$ & (2.39) \\
\hline Number of observations & 855 & 855 & 855 & 855 & 855 \\
\hline Log likelihood & -310.03 & -309.71 & -310.32 & -311.44 & -311.52 \\
\hline Pseudo $R^{2}$ & 0.155 & 0.156 & 0.154 & 0.151 & 0.151 \\
\hline Wald $\chi^{2}$ & $66.28^{* * *}$ & $66.01^{* * *}$ & $65.5^{* * *}$ & $62.97^{* * *}$ & $62.8^{* * *}$ \\
\hline
\end{tabular}

Note: ${ }^{* * *} \mathrm{p}<.01 ;{ }^{* *} \mathrm{p}<.05 ;{ }^{*} \mathrm{p}<.1$. Robust standard errors are in parentheses. 


\section{Appendix 1}

Table A1. Results without patents or without market size

\begin{tabular}{lll}
\hline & Model 1 without patents & Model 3 without market size \\
\hline Market size & $3.873^{* * * *}$ & \\
& $(0.64)$ & \\
Market size * Africa & $-2.778^{* * *}$ & \\
& $(0.98)$ & $0.460 * * *$ \\
Patents & & $(0.07)$ \\
& -0.118 \\
Patents * Africa & $(0.12)$ \\
\multicolumn{2}{l}{$\begin{array}{l}\text { Note: }{ }^{* * * *} \mathrm{p}<.01 ;{ }^{* *} \mathrm{p}<.05 ;{ }^{*} \mathrm{p}<.1 . \text { To save space the other explanatory variables though } \\
\text { included but not reported. }\end{array}$}
\end{tabular}

\section{References}

Aleksynska, M. \& Havrylchyk, O. (2013). FDI from the south: The role of institutional distance and natural resources. European Journal of Political Economy, 29, 38-53.

Aoki, M. \& Rothwell, G. (2013). A comparative institutional analysis of the Fukushima nuclear disaster: Lessons and policy implications. Energy Policy, 53, 240-247.

Asiedu, E. (2002). On the Determinants of Foreign Direct Investment to Developing Countries: Is Africa Different? World Development, 30, 107-119.

Asiedu, E. (2006). Foreign direct investment in Africa: The role of natural resources, market size, government policy, institutions and political instability. World Economy, 29, 63-77.

Asiedu, E. \& Villamil, A. P. (2000). Discount factors and thresholds: Foreign investment when enforcement is imperfect. Macroeconomic Dynamics, 4, 1-21.

Aybar, B. \& Ficici, A. (2009). Cross-border acquisitions and firm value: An analysis of emergingmarket multinationals. Journal of International Business Studies, 40, 1317-1338.

Bhaumik, S. K., Driffield, N. \& Zhou, Y. (2016). Country specific advantage, firm specific advantage and multinationality-Sources of competitive advantage in emerging markets: Evidence from the electronics industry in China. International Business Review, 25, 165176.

Biggeri, M. \& Sanfilippo, M. (2009). Understanding China's move into Africa: an empirical analysis. Journal of Chinese Economic and Business Studies, 7, 31-54. 
Boateng, A., Qian, W. \& Tianle, Y. (2008). Cross-border M\&As by Chinese firms: An analysis of strategic motives and performance. Thunderbird International Business Review, 50, 259270.

Brautigam, D. (2009). The dragon's gift: the real story of China in Africa. Oxford, UK: Oxford University Press.

Buckley, P. J., Clegg, L. J., Cross, A. R., Liu, X., Voss, H. \& Zheng, P. (2007). The determinants of Chinese outward foreign direct investment. Journal of International Business Studies, $38,499-518$.

Buckley, P. J., Yu, P., Liu, Q., Munjal, S. \& Tao, P. (2016). The institutional influence on the location strategies of multinational enterprises from emerging economies: Evidence from China's cross-border mergers and acquisitions. Management and Organization Review, 12, 425-448.

Bwalya, S. M. (2006). Foreign direct investment and technology spillovers: Evidence from panel data analysis of manufacturing firms in Zambia. Journal of Development Economics, 81, 514-526.

Chari, M. D. \& Chang, K. (2009). Determinants of the share of equity sought in cross-border acquisitions. Journal of International Business Studies, 40, 1277-1297.

Chari, M. D. \& Shaikh, I. A. (2017). Defying Distance? Cross-Border Acquisitions by EmergingEconomy Firms. Thunderbird International Business Review, 59, 173-186.

Chen, S. F. S. (2008). The motives for international acquisitions: Capability procurements, strategic considerations, and the role of ownership structures. Journal of International Business Studies, 39, 454-471.

Chen, W., Dollar, D. \& Tang, H. (2018). Why is China investing in Africa? Evidence from the firm level. World Bank Economic Review, 32, 610-632.

Cheung, Y. W., De Haan, J., Qian, X. \& Yu, S. (2012). China's outward direct investment in Africa. Review of International Economics, 20, 201-220.

Contractor, F. J., Lahiri, S., Elango, B. \& Kundu, S. K. (2014). Institutional, cultural and industry related determinants of ownership choices in emerging market FDI acquisitions. International Business Review, 23, 931-941

Cui, L. \& Jiang, F. (2009). FDI entry mode choice of Chinese firms: A strategic behavior perspective. Journal of World Business, 44, 434-444. 
Cui, L., Meyer, K. E. \& Hu, H. W. (2014). What drives firms' intent to seek strategic assets by foreign direct investment? A study of emerging economy firms. Journal of World Business, 49, 488-501.

Dacin, M. T., Goodstein, J. \& Scott, R. W. (2002). Institutional theory and institutional change: Introduction to the special research forum. Academy of Management Journal, 45, 45-56.

Davis, G. F. \& Cobb, J. A. (2010). Resource dependence theory: Past and future. In Schoonhoven, C.B. \& Frank Dobbin, F.(Eds). Stanford's organization theory renaissance, 1970-2000. Emerald Group Publishing Limited: UK.

Degbey, W. Y., \& Ellis, K. M. (2017). Africa: An emerging context for value creation with crossborder mergers and acquisitions. In S. Marinova, J. Larimo, \& N. Nummela (Eds.), Value creations in international business An MNC perspective (Vol. 1). London, England: Palgrave Macmillan.

Deng, P. (2009). Why do Chinese firms tend to acquire strategic assets in international expansion? Journal of World Business, 44, 74-84.

Deng, P. \& Yang, M. (2015). Cross-border mergers and acquisitions by emerging market firms: A comparative investigation. International Business Review, 24, 157-172.

Djankov, S., Glaeser, E., La Porta, R., Lopez-De-Silanes, F. \& Shleifer, A. (2003). The new comparative economics. Journal of Comparative Economics, 31, 595-619.

Du, J. \& Zhang, Y. (2018). Does One Belt One Road initiative promote Chinese overseas direct investment? China Economic Review, 47, 189-205.

Dunning, J. H., \& Lundan, S. M. (2008). Multinational enterprises and the global economy, $2^{\text {nd }}$ Edition. Cheltenham, UK: Edward Elgar Publishing.

Dunning, J. H. \& Lundan, S. M. (2008). Institutions and The OLI Paradigm of the Multinational Enterprise. Asia Pacific Journal Of Management, 25, 573-593.

Dupasquier, C. \& Osakwe, P. N. (2006). Foreign direct investment in Africa: Performance, challenges, and responsibilities. Journal of Asian Economics, 17, 241-260.

Ellis, K. M., Lamont, B. T., Reus, T. H. \& Faifman, L. (2015). Mergers and Acquisitions in Africa: A Review and an Emerging Research Agenda. Africa Journal of Management, 1, 137-171.

Ellis, K. M., Lamont, B. T., Holmes, R. M., Ro, S., Faifman, L., Deghetto, K. \& Parola, H. (2018). Institutional determinants of ownership positions of foreign acquirers in Africa. Global Strategy Journal, 8, 242-274. 
Financial Times (2017). China's Geely to take controlling stake in Lotus. Available: https://www.ft.com/content/19c854fc-3fcc-11e7-9d56-25f963e998b2 $\quad$ [Accessed $4^{\text {th }}$ March 2019].

Frynas, J. G. \& Paulo, M. (2006). A new scramble for African oil? Historical, political, and business perspectives. African Affairs, 106, 229-251.

Greif, A. (1998). Historical and comparative institutional analysis. American Economic Review, $88,80-84$.

Head, K. (2007). Elements of Multinational Strategy. US: Springer.

Kolstad, I. \& Wiig, A. (2011). Better the Devil You Know? Chinese Foreign Direct Investment in Africa. Journal of African Business, 12, 31-50.

Kolstad, I. \& Wiig, A. (2012). What determines Chinese outward FDI? Journal of World Business, 47, 26-34.

Leonard, D. K. \& Straus, S. (2003). Africa's stalled development: international causes and cures. Boulder, US: Lynne Rienner Publishers.

Liu, Y. \& Woywode, M. (2013). Light-Touch Integration of Chinese Cross-Border M\&A: The Influences of Culture and Absorptive Capacity. Thunderbird International Business Review, 55, 469-483.

Luiz, J. \& Stewart, C. (2014). Corruption, South African Multinational Enterprises and Institutions in Africa. Journal of Business Ethics, 124, 383-398.

Luo, Y. \& Tung, R.L. (2007). International Expansion of Emerging Market Enterprises: A Springboard Perspective. Journal of International Business Studies, 38, 481-498.

Managi, S. \& Bwalya, S. M. (2010). Foreign direct investment and technology spillovers in subSaharan Africa. Applied Economics Letters, 17, 605-608.

Malhotra, S., Zhu, P. \& Locander, W. (2010). Impact of host-country corruption on U.S. and Chinese cross-border acquisitions. Thunderbird International Business Review, 52, 491507.

Mourao, P.R. (2017). What is China seeking from Africa? An analysis of the economic and political determinants of Chinese Outward Foreign Direct Investment based on Stochastic Frontier Models. China Economic Review, 48, 258-268. 
Nicholson, R. R. \& Salaber, J. (2013). The motives and performance of cross-border acquirers from emerging economies: Comparison between Chinese and Indian firms. International Business Review, 22, 963-980.

North, D. C. (2005). Understanding the process of economic change. Princeton, N. J.: Princeton University Press.

Oguji, N., Degbey, W. Y., \& Owusu, R. A. (2018). International joint ventures research on Africa: A systematic literature review, propositions, and contextualization. Thunderbird International Business Review, 1-16.

Oguji, N. \& Owusu, R. A. (2017). Acquisitions entry strategies in Africa: the role of institutions, target-specific experience, and host-country capabilities - the case acquisitions of Finnish multinationals in Africa. Thunderbird International Business Review, 59, 209-225.

Oliver, C. 1997. Sustainable competitive advantage: Combining institutional and resource-based views. Strategic Management Journal, 18, 679-713.

Peng, M. W., Wang, D. \& Jiang , Y. ( 2008 ). An institution-based view of international business strategy: A focus on emerging economies. Journal of International Business Studies, 39, 920-936.

Reinhart, C. \& Rogoff, K. (2003). FDI to Africa: the role of price stability and currency instability. IDEAS Working Paper Series from RePEc. St. Louis: Federal Reserve Bank of St Louis.

Rogmans, T. \& Ebbers, H. (2013). The determinants of foreign direct investment in the Middle East North Africa region. International Journal of Emerging Markets, 8, 240-257.

Rui, H. \& Yip, G. S. (2008). Foreign acquisitions by Chinese firms: A strategic intent perspective. Journal of World Business, 43, 213-226.

Scott, R. W. (2013). Institutions and Organizations: Ideas, Interests and Identities, $4^{\text {th }}$ Edition. Thousand Oaks, California: SAGE Publications.

Taylor, I. (2009). China's new role in Africa. Boulder, US: Lynne Rienner Publishers.

Taylor, I. (2012). The forum on China-Africa cooperation (FOCAC). London: Routledge.

Transparency International (2018). Corruption Perceptions Index 2018. Available: https://www.transparency.org/cpi2018 [Accessed 30th September 2019].

UNCTAD (2019). World Investment Report 2018. Geneva: United Nations. 
Wahid, A., Sawkut, R. \& Seetanah, B. (2009). Determinants of Foreign Direct Investments (FDI): Lessons from the African Economies. The Journal of Applied Business and Economics, 9, 70-80.

Wang, C., Hong, J., Kafouros, M. \& Boateng, A. (2012). What drives outward FDI of Chinese firms? Testing the explanatory power of three theoretical frameworks. International Business Review, 21, 425-438.

World Bank. (2014). Foreign direct investment flows into Sub-Saharan Africa: Science, technology, and skills for Africa's development. Washington DC: World Bank Group.

Yang, M. \& Deng, P. (2017). Cross-Border M\&As by Chinese Companies in Advanced Countries: Antecedents and Implications. Thunderbird International Business Review, 59, 263-280. 